\title{
Contribution of the BRCA1 and BRCA2 mutations to breast cancer in Tunisia
}

\author{
Wafa Troudi - N. Uhrhammer $\cdot$ C. Sibille $\cdot$ C. Dahan $\cdot$ W. Mahfoudh \\ C. Bouchlaka Souissi - T. Jalabert · L. Chouchane - Y. J. Bignon · \\ F. Ben Ayed $\cdot$ A. Ben Ammar Elgaaied
}

Received: 28 May 2007/Accepted: 30 August 2007/Published online: 9 October 2007

(C) The Japan Society of Human Genetics and Springer 2007

\begin{abstract}
Hereditary breast cancer accounts for 3-8\% of all breast cancers, with mutations in the BRCA1 and BRCA2 genes responsible for up to $30 \%$ of these. To investigate the prevalence of BRCA1 and BRCA2 gene mutations in breast cancer patients with affected relatives in Tunisia, we studied 36 patients who had at least one first degree relative with breast and/or ovarian cancer Thirtyfour 34 patients were suggestive of the BRCA1 mutation and two were suggestive of the BRCA2 mutation, based on the presence of male breast cancer detected in their corresponding pedigrees. Four mutations in BRCA1 were detected, including a novel frame-shift mutation (c.211dupA) in two unrelated patients and three other frameshift mutations - c.4041delAG, c.2551delG and
\end{abstract}

W. Troudi $(\varangle) \cdot$ C. Bouchlaka Souissi .

A. Ben Ammar Elgaaied

Laboratory of Genetics, Immunology and Human Pathology,

Faculty of Sciences of Tunis, Universitaire El Manar I,

1060 Tunis, Tunisia

e-mail: Wafa_t@yahoo.com

W. Troudi · F. Ben Ayed

Salah Azaiez Institute of Carcinology of Tunis,

Boulevard 09 Avril, 1006 Bab Saadoun, Tunisia

N. Uhrhammer · T. Jalabert · Y. J. Bignon

Laboratoire Diagnostic Génétique et Moléculaire,

Centre Jean-Perrin, 63011 Clermont-Ferrand Cedex 01, France

C. Sibille - C. Dahan

Laboratory of Molecular Genetic of Hereditary Pathologies, Center of Human Genetics UCL, Avenue E. Mounier - Entrée F, 1200 Brussels, Belgium

W. Mahfoudh · L. Chouchane

Laboratory of Molecular Immuno-Oncology,

Faculty of Medicine, Monastir University, Avenue Avicenne,

Monastir 5019 Cedex, Tunisia
c.5266dupC. Our study is the first to describe the c.5266dupC mutation in a non-Jewish Ashkenazi population. Two frameshift mutations (c.1309del4 and c.5682insA) were observed in BRCA2. Nineteen percent (7/36) of the familial cases had deleterious mutations of the BRCA1 or BRCA2 genes. Almost all patients with deleterious mutations of BRCA1 reported a family history of breast and/or ovarian cancer in the index case or in their relatives. Our data are the first to contribute to information on the mutation spectrum of BRCA genes in Tunisia, and we give a recommendation for improving clinical genetic testing policy.

Keywords BRCA1 - BRCA2 - Breast cancer . Mutation analysis - Tunisia

\section{Introduction}

Breast cancer is the most common malignancy among women, with a lifetime risk of approximately $10 \%$. A family history of breast cancer is present in 5-10\% of all cases (Guran and Safali 2005). Carcinoma of the breast is the most common cancer among women in Tunisia, with an agestandardized rate (ASR) of 16.7 per 100,000 per year. Average age at diagnosis is 50 years (Charef-Hamza et al. 2005).

The BRCA1 and BRCA2 genes are associated with inherited susceptibility to breast and ovarian cancer, and mutations in these two genes are thought to account for about $6-10 \%$ of all breast/ovarian cancers (Szabo and King 1997). To date, more than 3400 distinct germline BRCA1/2 mutations, polymorphisms and sequence variants with unverified significance have been identified throughout the coding regions of both genes (Breast Cancer Information Core, BIC 
http://research.nhgri.nih.gov/bic/). Although analysis of BRCA1/2 mutations has greatly increased our understanding of breast cancer genetics in Western populations, little is known about the frequency and types of mutations in the Tunisian population.

We present the clinical diagnosis and results of a molecular germline analysis of 36 patients referred to the Salah Azaiez Institute with the suspicion of familial breast cancer. Mutation screening for the BRCA1 and BRCA2 genes was carried out in selected families. The initial risk assessment of breast cancer was based on family history and pedigree (Harris et al. 1992). All of the cases were selected on the basis of selected criteria adopted by other investigators (Kennedy et al. 2002) that indicate the importance of BRCA1 or BRCA2 mutation screening.

\section{Materials and methods}

\section{Patients and selection criteria}

Thirty-six patients were chosen with a suspicion of familial breast cancer. Data on the occurrence of various tumors (breast cancer, ovarian cancer and other types of tumors), histopathological characteristics and pedigree data were collected. In addition, age at initial diagnosis was recorded. Personal and familial cancer histories were obtained from these patients and some relatives who agreed to participate in the study. For genomic DNA testing, the project has been approved by Salah Azaiez Institute of Carcinology ethics committee, and informed consent was obtained from each patient.

BRCA1 mutation suggestivity in familial breast cancer is defined as the index case of family with at least three female relatives affected with breast and/or ovarian cancer and the absence of male breast cancer. In the cases of families with fewer than three affected relatives, the following factors were taken into account: (1) one relative (or the person considering testing) was diagnosed with breast or ovarian cancer before age 45 or (2) one member of the family was diagnosed with ovarian cancer and at least one family member on the same side was diagnosed with breast cancer (at any age) or (3) one relative (or the person considering testing) was diagnosed with multiple primary breast cancers, or (4) one relative has been identified with a BRCA mutation.

The presence of a male proband or a male relative diagnosed with breast cancer is suggestive of BRCA2 mutation (Arena et al. 1996).

\section{BRCA1 and BRCA2 mutations}

Genomic DNA was first extracted from peripheral blood mononuclear cells isolated from each sample by means of
Proteinase $\mathrm{K}$ digestion and then column-purified (Qiagen, Chatsworth, CA). The BRCA1 and BRCA2 exons were PCR amplified in a total reaction volume of $50 \mu \mathrm{l}$ containing $10 \mathrm{~m} M$ Tris- $\mathrm{HCl}, \mathrm{pH} 8.3,50 \mathrm{~m} M \mathrm{KCl}, 1.5-4.5 \mathrm{~m} M$ $\mathrm{MgCl}_{2}, 50 \mathrm{~m} M$ dNTPs, $10 \mu M$ of each primer (designed by Centre Jean Perrin; sequences available on demand), 100 ng of genomic DNA and 1 U of either Taq polymerase or AmpliTaq Gold (PE Biosystems, Foster City, CA). The PCR cycling program comprised an initial denaturation at $95^{\circ} \mathrm{C}$ for $10 \mathrm{~min}$, followed by 30 cycles of $94^{\circ} \mathrm{C}$ for $20 \mathrm{~s}$, annealing at specific temperatures for each primer pair and extension at $72^{\circ} \mathrm{C}$ for $45 \mathrm{~s}$. Twenty-four exons of the BRCA1 gene and 27 exons of the BRCA2 gene were analyzed by direct sequencing. The BRCA1 exon 11 was separated into nine fragments, the BRCA2 exon 11 was separated into 13 fragments and exon 10 was separated into three fragments.

\section{Sequencing}

Amplicons were purified by solid-phase extraction by QIAquick column gel purification (QIAGEN). The product was sequenced in forward and reverse reactions using the Applied Biosystems Taq DyeDeoxy terminator cycle sequencing kit according to the manufacturer's instructions. Cycle sequencing consisted of 25 cycles of $96^{\circ} \mathrm{C}$ for $30 \mathrm{~s}$ and $60^{\circ} \mathrm{C}$ for $30 \mathrm{~s}$. Sequence analysis was performed using Seqman (DNAstar, Madison, WI) and SEQScape V2.5 (Applied Biosystems) software.

\section{Results}

Thirty-six patients varying in age from 24 to 66 years (median age 56.8 years) were analyzed for hereditary breast cancer syndrome. Twenty-five index cases were diagnosed with breast cancer, five with bilateral breast cancer, five with both breast and ovarian cancer and one with ovarian cancer. On the basis of the pedigree analysis, the patients' families were classified in three groups:

Group A: breast and/or ovarian cancer in the same individual and more than one relative diagnosed for breast and/or ovarian cancer (11 families; 30.5\%);

Group B: more than one (up to three) case of breast cancer in the family without ovarian cancer (23 families; $63.8 \%)$;

Group C: At least one case of male breast cancer (two families; $5.5 \%$ ). (Table 1 )

Mutation analysis of the BRCA1 and BRCA2 was performed in these 36 index cases. Overall, six deleterious mutations were identified among seven unrelated patients 
Table 1 Characteristics of breast/ovarian cancer patients and relatives
$\mathrm{Br}$, Breast cancer; Ov, ovarian cancer; $\mathrm{Bi}, \mathrm{Br}$ bilateral breast cancer; $\mathrm{M} \mathrm{Br}$, male breast cancer

a Patient with BRCA1/2 mutation

\begin{tabular}{|c|c|c|c|c|c|c|}
\hline Patient group & Patient & Age & Probands & First degree relatives & $\begin{array}{l}\text { Second degree } \\
\text { relatives }\end{array}$ & $\begin{array}{l}\text { Third degree } \\
\text { relatives }\end{array}$ \\
\hline \multirow[t]{11}{*}{ A } & 1 & 66 & $\mathrm{Ov}$ & $3 \mathrm{Br}$ & 0 & 0 \\
\hline & 2 & 43 & $\mathrm{Br}$ & $10 v$ & $1 \mathrm{Br}$ & 0 \\
\hline & $3^{\mathrm{a}}$ & 54 & $\mathrm{Br}+\mathrm{Ov}$ & 0 & 0 & 0 \\
\hline & 4 & 39 & $\mathrm{Br}+\mathrm{Ov}$ & 0 & 0 & $2 \mathrm{Br}$ \\
\hline & $5^{\mathrm{a}}$ & 50 & $\mathrm{Br}+\mathrm{Ov}$ & 0 & 0 & $1 \mathrm{Ov}$ \\
\hline & $6^{\mathrm{a}}$ & 65 & $\mathrm{Br}+\mathrm{Ov}$ & $1 \mathrm{Br}$ & 0 & 0 \\
\hline & 7 & 58 & $\mathrm{Bi} . \mathrm{Br}$ & $1 \mathrm{Ov}$ & $1 \mathrm{Ov}$ & $2 \mathrm{Br}+\mathrm{Ov}$ \\
\hline & $8^{\mathrm{a}}$ & 45 & $\mathrm{Br}$ & $2 \mathrm{Br}$ & 0 & $2 \mathrm{Br}+\mathrm{Ov}$ \\
\hline & 9 & 36 & $\mathrm{Br}$ & $1 \mathrm{Br}$ & 0 & $1 \mathrm{Ov}$ \\
\hline & 10 & 40 & $\mathrm{Br}+\mathrm{Ov}$ & 0 & 0 & 0 \\
\hline & $11^{\mathrm{a}}$ & 45 & $\mathrm{Br}$ & $1 \mathrm{Br}+\mathrm{Ov}$ & $1 \mathrm{Br}$ & $10 \mathrm{v}$ \\
\hline \multirow[t]{23}{*}{ B } & 12 & 41 & $\mathrm{Br}$ & $2 \mathrm{Br}$ & $1 \mathrm{Br}$ & 0 \\
\hline & 13 & 46 & $\mathrm{Br}$ & $1 \mathrm{Br}$ & 0 & 0 \\
\hline & 14 & 24 & $\mathrm{Bi} \cdot \mathrm{Br}$ & 0 & 0 & $1 \mathrm{Br}$ \\
\hline & $15^{\mathrm{a}}$ & 47 & $\mathrm{Br}$ & $1 \mathrm{Br}$ & 0 & 0 \\
\hline & 16 & 53 & $\mathrm{Bi} \cdot \mathrm{Br}$ & $1 \mathrm{Br}$ & 0 & 0 \\
\hline & 17 & 38 & $\mathrm{Bi} \cdot \mathrm{Br}$ & 1 & 1 & 1 \\
\hline & 18 & 41 & $\mathrm{Br}$ & $2 \mathrm{Br}$ & 0 & 0 \\
\hline & 19 & 42 & $\mathrm{Br}$ & $2 \mathrm{Br}$ & 0 & 0 \\
\hline & 20 & 37 & $\mathrm{Br}$ & 0 & $2 \mathrm{Br}$ & 0 \\
\hline & 21 & 52 & $\mathrm{Br}$ & 0 & $2 \mathrm{Br}$ & 0 \\
\hline & 22 & 58 & $\mathrm{Br}$ & 0 & $1 \mathrm{Br}$ & $2 \mathrm{Br}$ \\
\hline & 23 & 38 & $\mathrm{Br}$ & $1 \mathrm{Br}$ & $1 \mathrm{Br}$ & $2 \mathrm{Br}$ \\
\hline & 24 & 58 & $\mathrm{Br}$ & $1 \mathrm{Br}$ & $1 \mathrm{Br}$ & 0 \\
\hline & 25 & 41 & $\mathrm{Br}$ & 0 & $1 \mathrm{Br}$ & $2 \mathrm{Br}$ \\
\hline & 26 & 50 & $\mathrm{Br}$ & $2 \mathrm{Br}$ & 0 & 0 \\
\hline & 27 & 44 & $\mathrm{Br}$ & $1 \mathrm{Br}$ & 0 & 0 \\
\hline & 28 & 45 & $\mathrm{Br}$ & $1 \mathrm{Br}$ & $1 \mathrm{Br}$ & 0 \\
\hline & 29 & 45 & $\mathrm{Br}$ & $1 \mathrm{Br}$ & 0 & 0 \\
\hline & 30 & 40 & $\mathrm{Br}$ & $1 \mathrm{Br}$ & 0 & $1 \mathrm{Br}$ \\
\hline & 31 & 42 & $\mathrm{Br}$ & 0 & 0 & $2 \mathrm{Br}$ \\
\hline & 32 & 57 & $\mathrm{Br}$ & $1 \mathrm{Br}$ & $1 \mathrm{Br}$ & $1 \mathrm{Br}$ \\
\hline & 33 & 46 & $\mathrm{Br}$ & $1 \mathrm{Br}$ & 0 & 0 \\
\hline & 34 & 55 & $\mathrm{Br}$ & $1 \mathrm{Br}$ & $1 \mathrm{Br}$ & 0 \\
\hline \multirow[t]{2}{*}{$\mathrm{C}$} & $35^{\mathrm{a}}$ & 39 & $\mathrm{Br}$ & $1 \mathrm{M} \mathrm{Br}$ & 0 & 0 \\
\hline & 36 & 66 & Bi.M.Br & 0 & 0 & 0 \\
\hline
\end{tabular}

(19.4\%), four in BRCA1 and two in BRCA2. Table 2 shows the clinical features of BRCA1/2 mutation-positive patients, and Table 3 presents both the Human Genome Organization (HUGO) approved systematic nomenclature and the Breast Cancer Information Core (BIC) traditional nomenclature of the BRCA1 and BRCA2 mutations identified. In addition to these mutations, we identified nine distinct unclassified sequence variants (eight UV in BRCA1 and one in BRCA2) and 16 distinct polymorphisms (12 in BRCA1 and four in BRCA2) (Table 4).

All the deleterious mutations detected in this study were small deletions $(n=3)$ or insertions $(n=3)$ resulting in frame-shifts. A search of the BIC database revealed that five of these BRCA1/2 mutations were already in the database; one mutation, the c.211dupA mutation, was not found in the BIC database and therefore considered by the authors to be novel (Fig. 1). This mutation was found in two unrelated patients.

Five families from Group A had a mutation: four in the BRCA1 gene (c.2551delG, c.4041delAG, c.5266dupC, c.211dupA) and one in the BRCA2 gene (c.5682insA). This last BRCA2 mutation was found in a family suggestive of the BRCA1 mutation: the proband aged 45 years was diagnosed for breast cancer, and histological analyses 
Table 2 Clinical-pathological characteristics in subgroups of breast cancer patients with BRCA1/2 deleterious mutations

\begin{tabular}{|c|c|c|c|c|c|c|c|}
\hline Patient & $\begin{array}{l}\text { Age at diagnosis } \\
\text { (years) }\end{array}$ & Histology & Histological grade & Lymph node status & T stage & ER status & PR status \\
\hline 3 & 54 & IDC & 3 & + & & - & - \\
\hline 5 & 50 & IDC & 3 & + & II & - & - \\
\hline 6 & 65 & IDC & 2 & ND & I & + & + \\
\hline 8 & 45 & IDC & 3 & + & II & ND & ND \\
\hline 11 & 45 & IDC & & ND & ND & ND & ND \\
\hline 15 & 47 & IDC & 3 & + & II & - & - \\
\hline 35 & 39 & & & & $\mathrm{C}$ in situ & - & + \\
\hline
\end{tabular}

IDC, Infiltrative ductal carcinoma; C, carcinoma; ER, estrogen receptor; PR, progesterone receptor; ND, non-determined

Table 3 BRCA1/2 deleterious mutations

\begin{tabular}{|c|c|c|c|c|c|c|}
\hline Groups & Patient & Gene & Exon & Sequence variant & BIC traditional nomenclature & Amino acid change \\
\hline \multirow[t]{4}{*}{ Group A } & 5 & BRCA1 & 20 & c.5266dupC & 5385 ins $\mathrm{C}$ & Stop 1829 \\
\hline & 6 & BRCA1 & 11 & c.4041delAG & 4160 delAG & Stop 1354 \\
\hline & 8 & BRCA1 & 11 & c. $2551 \mathrm{delG}$ & 2789 del G & Stop 892 \\
\hline & 11 & BRCA2 & 11 & c.5682insA & 5909 ins A & Stop 1894 \\
\hline Group A + B & 3 and 15 & BRCA1 & 5 & c.211dupA & 330 dup A & Stop 79 \\
\hline Group C & 35 & BRCA2 & 10 & c.1309del4 & 1537 del4 & Stop 459 \\
\hline
\end{tabular}

BIC database, Breast Cancer Information Core database

indicated infiltrative ductal carcinoma. The same mutation was found in her sister, aged 44 years, who had been operated on for bilateral ovarian cancer; other relatives were diagnosed for breast or ovarian carcinoma or other cancers.

The c.211dupA mutation in BRCA1 was detected in one of the 23 families from Group B, and the BRCA2 c.1309del4 mutation was detected in one family from Group C. Thus. among the three groups, BRCA1/2 mutations were more frequent in those individuals with ovarian cancer $(5 / 11)$ and in those of group $C(1 / 2)$, and they were not frequent in group B patients $(1 / 23)$.

\section{Discussion}

Hereditary breast-ovarian cancer may be recognized through examination of clinical data and pedigree findings which may direct molecular genetic testing. Mutations in BRCA1 and BRCA2 have an important role in hereditary breast-ovarian cancer syndrome (Harris et al. 1993). For the risks of having BRCA1/BRCA2 mutations, two criteria are important: the number of cases of breast and/or ovarian cancer in the family and the age of onset (Pekins and Waude 1993; Vahteristo et al. 2001).

To date, very few reports have been published about the spectrum of BRCA1 and BRCA2 mutations from the Tunisian population (Charef-Hamza et al. 2005). No hotspot regions were reported (Yazici et al. 2000, 2002). Because these genes are rather large, mutation detection is laborious and expensive.

In the present study, we sought to evaluate the mutational spectrum and frequency of germline BRCA1 and BRCA2 mutations in Tunisian breast cancer patients with risk factors evaluated through the familial pedigree. Among 36 patients analyzed, 5 (14\%) carried deleterious mutations in BRCA1 and $2(5.5 \%)$ in BRCA2. This finding is in agreement with previous results showing that the frequency of BRCA1 mutations is 1.5-2.0 fold higher than the frequency of BRCA2 mutations in all regions other than Iceland (Szabo and King 1997).

Among the six distinct mutations identified in this study, only one (c.211dupA) had not been described previously. Since the number of Tunisian patients analyzed to date is too small to exclude the possibility of founder mutations, we cannot eliminate entirely the possibility that this mutation found in two unrelated patients could have a particular ethnic origin. However, the BRCA1 mutation c.5266dupC was detected in one of the families with a history of breast and ovarian cancer; this mutation is common in the Ashkenazi Jewish population, but rare in the Tunesian population. This result suggests that mutations specific to ethnic groups should be taken into account along with familial and clinical presentation.

Ahn et al. (2007) reported that among Korean breast cancer patients the frequency of the mutation increased 
Table 4 Polymorphisms and unclassified variants in BRCA $1 / 2$
UV, Unclassified variant

a According to HUGO (Human Genome Organization) approved systematic nomenclature

b According BIC traditional nomenclature

c Frequency of genotypes with mutation at heterozygous state

Fig. 1 Mutated BRCA1 sequence (c.211dupA mutation). The gray region corresponds to the beginning of intron 5 of the BRCA1 gene. The uncolored region corresponds to the end of the exon 5BRCA1 gene. The mutation is located at the level of the splicing donor site of exon 5 (black arrow)

\begin{tabular}{|c|c|c|c|c|}
\hline Mutation type & Sequence variant ${ }^{\mathrm{a}}$ & Base change $^{\mathrm{b}}$ & Amino acid change & $\begin{array}{l}\text { Frequency }{ }^{\mathrm{c}} n \\
=36(100 \%)\end{array}$ \\
\hline \multicolumn{5}{|l|}{ BRCA1 } \\
\hline \multirow[t]{12}{*}{ Polymorphisms } & c. $2082 \mathrm{C}>\mathrm{T}$ & $2201 \mathrm{C}>\mathrm{T}$ & p.S694S & $25 \%$ \\
\hline & c. $2077 \mathrm{G}>\mathrm{A}$ & $2196 \mathrm{G}>\mathrm{A}$ & p.D693N & $11 \%$ \\
\hline & c. $2341 \mathrm{~T}>\mathrm{C}$ & $2460 \mathrm{~T}>\mathrm{C}$ & p.C801R & $8 \%$ \\
\hline & c. $2612 \mathrm{C}>\mathrm{T}$ & $2731 \mathrm{C}>\mathrm{T}$ & p.P871L & $28 \%$ \\
\hline & c. $3119 \mathrm{~A}>\mathrm{G}$ & $3238 \mathrm{~A}>\mathrm{G}$ & p.S1041G & $39 \%$ \\
\hline & c. $3113 \mathrm{~A}>\mathrm{G}$ & $3232 \mathrm{~A}>\mathrm{G}$ & p.E1038G & $3 \%$ \\
\hline & c. $3548 \mathrm{~A}>\mathrm{G}$ & $3667 \mathrm{~A}>\mathrm{G}$ & p.K1183R & $25 \%$ \\
\hline & c. $4837 \mathrm{~A}>\mathrm{G}$ & $4956 \mathrm{~A}>\mathrm{G}$ & p.S1613G & $25 \%$ \\
\hline & c. $442-58$ delT & IVS $8(-58)$ delT & & $11 \%$ \\
\hline & c. $4308 \mathrm{~T}>\mathrm{C}$ & $4427 \mathrm{~T}>\mathrm{C}$ & p.S1436S & $14 \%$ \\
\hline & c. $2311 \mathrm{~T}>\mathrm{C}$ & $2430 \mathrm{~T}>\mathrm{C}$ & p.L771L & $11 \%$ \\
\hline & c. $4113 \mathrm{G}>\mathrm{A}$ & $4232 \mathrm{G}>\mathrm{A}$ & p.G1371G & $3 \%$ \\
\hline \multirow[t]{8}{*}{ UV mutations } & c. $1832 \mathrm{~T}>\mathrm{C}$ & $1951 \mathrm{~T}>\mathrm{C}$ & p.L611P & $3 \%$ \\
\hline & c. $4538 \mathrm{G}>\mathrm{A}$ & $4657 \mathrm{G}>\mathrm{A}$ & p.C1513Y & $3 \%$ \\
\hline & c. $2529 \mathrm{C}>\mathrm{T}$ & $2640 \mathrm{C}>\mathrm{T}$ & p.R841W & $3 \%$ \\
\hline & c. $5117 \mathrm{G}>\mathrm{C}$ & $5236 \mathrm{G}>\mathrm{C}$ & p.G1706A & $3 \%$ \\
\hline & c. $1648 \mathrm{~A}>\mathrm{C}$ & $1767 \mathrm{~A}>\mathrm{C}$ & p.N550H & $3 \%$ \\
\hline & c. 4882 A $>$ G & $5001 \mathrm{~A}>\mathrm{G}$ & p.M1628M & $5 \%$ \\
\hline & c. $4956 \mathrm{G}>\mathrm{A}$ & $5075 \mathrm{G}>\mathrm{A}$ & p.M1652I & $3 \%$ \\
\hline & c. $4600 \mathrm{G}>\mathrm{A}$ & $4719 \mathrm{G}>\mathrm{A}$ & p.V1534M & $3 \%$ \\
\hline \multicolumn{5}{|l|}{ BRCA2 } \\
\hline \multirow[t]{4}{*}{ Polymorphisms } & c. $-25 \mathrm{G}>\mathrm{A}$ & $203 \mathrm{G}>\mathrm{A}$ & 5 ' untranslated region $5^{\prime}$ UTR & $8 \%$ \\
\hline & c. $6301 \mathrm{~A}>\mathrm{C}$ & $6529 \mathrm{~A}>\mathrm{C}$ & p.N2101H & $3 \%$ \\
\hline & c. $1595 \mathrm{~A}>\mathrm{T}$ & $1823 \mathrm{~A}>\mathrm{T}$ & p.E532V & $3 \%$ \\
\hline & c. 7242 A $>$ G & $7470 \mathrm{~A}>\mathrm{G}$ & p.S2414S & $5 \%$ \\
\hline UV mutations & c. $865 \mathrm{~A}>\mathrm{G}$ & $1093 \mathrm{~A}>\mathrm{G}$ & p.N289H & $3 \%$ \\
\hline
\end{tabular}

C.211dupA mutation

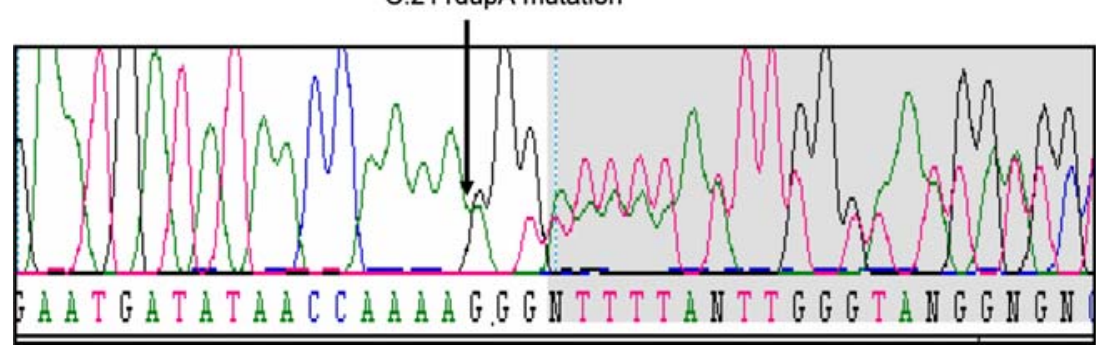

with the number of affected family members. Our results are not in agreement with this earlier finding since we did not detect any deleterious mutation in six families belonging to group B with more that four relatives with breast cancer. We found instead that the presence of at least one case of ovarian cancer in the index case or in the relatives may increase the probability of detecting a BRCA1/2 mutation.

BRCA2 c.5682insA was found in a family highly suggestive of BRCA1 mutation according to the selection criteria adopted in the present study. It has been proposed that families with mutations in the ovarian cancer cluster region (OCCR) of BRCA2 exon 11 (nucleotides 3035-6629) express a higher ratio of ovarian to breast cancer than families with mutations elsewhere in the gene (Lubinski et al. 2004). This could provide new guidelines in the selection criteria adopted for the screening of BRCA1/2 mutations in Tunisian patients.

BRCA1 c.211dupA was found in two patients belonging to groups $\mathrm{A}$ and $\mathrm{B}$. This indicates that along with BRCA1/2 mutations, which are major factors in familial breast cancer, other genetic and environmental minor factors are involved in the familial presentation of the disease. 
In conclusion, we analyzed 36 Tunisian breast cancer patients with risk factors for germline mutations in the BRCA1 and BRCA2 genes. We found six mutations in seven unrelated patients $(19.4 \%)$. Detailed examination of the clinical data and pedigree findings in combination with molecular germline diagnosis are important for counseling of patients with familial breast cancer. Our data are the first to contribute information on the mutation spectrum of BRCA genes in Tunisia. Based on our results, we make the following recommendations for clinical genetic testing policy. (1) when breast/ovarian cancer is diagnosed in Tunisian families (group A), the molecular analysis should be directed to sequencing the BRCA1 gene and OCCR region of the BRCA2 gene, as there is about a $50 \%$ of probability of finding a mutation (five mutated cases among the 11 patients belonging to group A). (2) Given the presence of male breast cancer, the molecular analysis should be directed to sequencing the BRCA2 gene with about a $50 \%$ of probability of detecting a mutation in this gene (one mutated case among two belonging to group $\mathrm{C}$ ).

Families belonging to group B have a low probability of presenting a deleterious mutation in the BRCA1 gene (under $5 \%$ based on the $1 / 23$ cases from group B). More investigations are needed to further assess the frequency of BRCA2 mutations in this group.

Acknowledgments This study was funded in part by the Laboratory of Molecular genetics, Immunology and Human Pathologies at the Faculty of Science of University Tunis El Manar, the Institute of Carcinology Salah Azaiez and the Laboratory of Carcinology at the Faculty of Medicine of the University of Monastir. It was supported by IncoMed project Number ICA-CT-2002-10005. We wish to thank Aurélie Cassanhes (Centre Jean Perrin) and Xavier Pepermans (Center of Human Genetics UCL) for their technical support.

\section{References}

Ahn S, Son BH, Yoon KS, Noh DY, Han W, Kim SW, Lee ES, Park HL, Hong YJ, Cho DY et al. (2007) BRCA1 and BRCA2 germline mutations in Korean breast cancer patients at high risk of carrying mutations. Cancer Lett 245:90-95

Arena JF, Smith S, Plewinska M et al (1996) BRCA1 mutations in African American women. Am J Hum Genet 59[Suppl]:A34

Charef-Hamza S, Trimeche M, Ziadi M, Amara K, Gaddas N, Mokni M (2005) Loss of heterozygosity at the BRCA1 locus in Tunisian women with sporadic breast cancer. Cancer Lett 224:185-191

Guran S, Safali M (2005) A case of neurofibromatosis and breast cancer: loss of heterozygosity of NF1 in breast cancer. Cancer Genet Cytogenet 156:86-88

Harris JR, Lippmann ME, Veronesi U, Willett W (1992) Breast cancer (part A). N Engl J Med 327:319-328

Harris JR, Morrow M, Bonadonna G (1993) Cancer of the breast. In: De Vita VT, Hellman S, Rosenberg SA (eds) Cancer principles and practice of oncology, 4th edn. Lippincott, Philadelphia, pp 1264-1332

Lubinski J, Phelan CM, Ghadirian P, Lynch HT, Garber J, Weber B, Tung N, Horsman D, Isaacs C, Monteiro AN, Sun P, Narod SA (2004) Cancer variation associated with the position of the mutation in the BRCA2 gene. Fam Cancer 3:1-10

Kennedy RD, Quinn JE, Johnston PG, Harkin DP (2002) BRCA1: mechanisms of inactivation and implications for managements of patients. Lancet 360:1007-1014

Pekins AS, Waude GFV (1993) Principles of molecular cell biology of cancer: oncogenes. In: De Vita VT, Hellmann S, Rosenberg SA (eds) Cancer principles and practice of oncology, 4th edn. Lippincott, Philadelphia, pp 1264-332

Szabo CI, King MC (1997) Population genetics of BRCA1 and BRCA2. Am J Hum Genet 60:1013-1020

Vahteristo P, Eerola H, Tamminen A, Blomqvist C, Nevanlinna H (2001) A probability model for predicting BRCA1 and BRCA2 mutations in breast cancer and breast-ovarian cancer families. $\mathrm{Br}$ J Cancer 84:704-708

Yazici H, Bitisik O, Akisik E, Cabioglu N, Saip P, Muslumanoglu M, Glendon G, Bengisu E, Ozbilen S, Dincer M, Ozcelik H et al (2000) BRCA1 and BRCA2 mutations in Turkish breast/ovarian families and young breast cancer patients. Br J Cancer 83:737742

Yazici H, Glendon G, Yazici H, Burnie SJ, Saip P, Buyru F, Bengisu E, Andrulis IL, Dlay N, Ozcelik H (2002) BRCA1 and BRCA2 mutations in Turkish familial and non familial ovarian cancer patients: a high incidence of mutations in non familial cases. Hum Mutat 20:28-34 